\title{
Psychology of moral improvement of a person
}

\author{
O. Melnyk \\ National University of Physical Education and Sport of Ukraine \\ G.S. Kostiuk Institute of Psychology of the National Academy of Educational Sciences of Ukraine \\ Corresponding author. E-mail: melnyk-phd@yandex.com
}

Paper received 24.01.2018; Revised 28.01.18; Accepted for publication 29.01.18.

https://doi.org/10.31174/SEND-PP2018-154VI64-18

Abstract. In this article are represented the results of historical-psychological reconstruction of scientific ideas of Ukrainian representatives of university psychology of 19-th - and the beginning of 20-th century. In this work firstly is presented an ethical principle as methodology base of human cognition in university psychology in above mentioned period. Also firstly are proposed the scientific ideas of psychology teachers in Ukrainian universities concerning role of moral improvement in forming a personality, and ways of its achieving.

Keywords: human, ethical principle, moral improvement, freedom.

Introduction: Nowadays, when we become witnesses and participators of globalization processes, that take place all around the world, psychologists, who work in ranges of humanistic approach worry about rapid losing of interest, devaluation, and sometimes elimination everything ethical in human, his/her nature by those, who try to become a lord of the world so desperately. We want to warn and prevent this, because humanity, in order not to perish, has to develop according to ethical approach, and it was known and it has been shown in philosophical-psychological works of prominent scientists, the representatives of Ukrainian university psychology of 19-th - and the beginning of 20-th century, whose ideas, according to research we represent further.

A purpose of this publication: carrying out a historicalpsychological reconstruction of scientific ideas concerning the ways of moral improvements of human by representatives of Ukrainian university psychology of 19-th - and the beginning of 20-th century.

The resources for this research have become not well known and not well researched works of psychology teachers in Ukrainian universities.

Methods of research: a historical-genetic method, a historical-functional method, a comparing-historical method, a method of systematization of scientific ideas, a reconstructive method.

Along the way of life to moral improvement, from the point of representatives of Ukrainian university psychology, a human faces with two types of obstacles: direct ("the closest") and indirect ("remote") [1, p. 32]. The direct obstacles are: insufficient and not correct cognition of moral law, weakness of moral feelings, domination of natural and sensual tendencies over ethical behavior. The indirect obstacles are different cases and things, that facilitate revealing the human's drawbacks: youth inexperience, different temperaments, bad education and studying, relationships and communication with people, who behave not ethically. In addition, here are wealth and poorness, high and low status in society. In other words, the ethical principle declares compliance with extent in everything.

In case, if obstacles concerning human improvement were only external, for instance natural disasters, then achieving moral perfection would be not easy but still possible. Because among representatives of Ukrainian university psychology prevails idea, that the morality of human, virtue depends on internal attitude of human, but not external casual reasons. The weightiest obstacles in improvement process are psychological peculiarities of human. By this reason, for moral improvement a person needs absolute change of internal attitudes, creating new goals in life, like to born again. In order to follow aim, a person should focus all strengths and wills and choose life according to moral law, sticking to it all lifelong. And only from a person oneself, his/her will, actions and behavior, depend does this person prefer moral improvement, or he/she will be inactive and will remain the same in future. Because life according to moral principles requires from person constant work on oneself, and on his/her internal world just for improvement. In case of ceasing this work, the improvement process stops.

The representatives of Ukrainian university psychology of 19-th - and the beginning of 20-th century don't leave a person alone with mentioned tasks. Their scientific ideas propose the following psychological means:

1. A necessity of carrying self-analyze of own judgments and will displays

2. Do not waist own time behaving inactively

3. Enriching your knowledge

4. To heed your internal voice - conscience, analyze your actions, and do not try to forgive or ignore them

5. Before doing something, a human should think over, examine an ethical side of issue

6. For managing own feeling and passions a human must use external means depending on own temperaments and condition, at current moment of time

7. For solving passions, that have physical nature, is necessary to avoid cases, objects, people that provoke them, get rid of objects, that arouse them

8. For solving passions, that have internal or mental nature, is useful to activate your imagination concerning those things, objects, that will promote overcoming negative states, replay imagination and create images of imaginations, that counteract them, and train this ability.

A display of human morality is possible only full: internal and external. First, internal is a change, correction of negative feelings temptations. Second, external person's life, is a change of actions and human behavior according to ethical standards. That's why, moral improvement needs both of them. It is not worth to work on own character, but do not display this in real life, in actions. And at the same time, done actions in life, may not be the indicator of internal improvement in human perfection, because temptations not obligatory can be moral. And the main point is that moral way of life has to be constant and do not decay. A human never should think, that he/she has reached 
perfection: his/her responsibility is to strive for perfection, to develop, to seek the best, and be ready to overcome difficulties, the main of which are in human's conscience, in his/her internal, deep world.

The ethical principle means the availability of certain attitudes and responsibilities of human: to oneself, and to others.

The main point in attitude to yourself is self-preservation and improvement. In Ukrainian university psychology under term of self-preservation is meant the following: saving own life and health, saving possession, saving honour. Let's examine all these statements.

A commitment of saving own life and health. A life of human is a gift, and health - is the most important condition in life, that's why their saving is a commitment for a person. It encourages a human, from the point of view of teachers who taught psychology in 19-th - and the beginning of 20-th century, is an instinct, that a human is born with - a love to life, and it is inherent in every alive creature. And according to ethical standards, life is given to human also for education, that is one of the most important condition for forming high-moral person.

In scientific ideas we find advices. For instance, Ivan Skvorcev considers, that for saving health, a human should refrain from alcoholism, overeating and excessive luxury. All this can enervate a human's body, shorten his/her life and influence on mind. They can simply turn to habits, a necessity of their repeat, and thus lead to creation of inevitable negative chain. The main suggestions are proposed for saving health: limitation of life needs, physical training, working on disadvantages of own temperament, converting them to advantages (for instance train phlegmatic temperament to activity, and choleric to moderation and calmness).

However, human's life is priceless gift, "the biggest good" has own limits and once ends, is temporary corresponding to "moral good". And due to this, a human is higher than animal. But it is not allowed to expose own life to danger where there is no higher commitment, i.e. if a human wants to show audacity and courage.

The biggest enemy of self-preservation is a suicide deliberate homicide. There is a question: how a suicide is possible in universal law, when every creature in nature tries to preserve oneself, but not to destroy? The representatives of Ukrainian university psychology considered, that animals are not able to commit a suicide and that's why it is "miserable advantage of human" $[3, p$. 43]. The scientists considered that a suicide happens more often in teenage age. The most likely reason for this is that requirements of feelings and will, prevail over natural selfpreservation instinct. Thus, ethical principle and moral law forbid any suicide. Any difficulties in life, can't excuse it this is a Feofan's Avsenyev point of view - the life is given to human for higher aims.

Commitment to possession. In order to support own life and to reach useful goals, a person has not only right but also a commitment to save own possession, or otherwise, a person would be a parasite in society, he/she would be a burden for other people - this is a professor's point of view. This general commitment means: a commitment to economy, commitment to estimation and work. But in order not to make these commitments immoral, not to become drawback, it is necessary to stick to certain rules: consider possession as a means for other aims. If a person doesn't stick to this rule, he/she will become stingy, prodigal or mercenary.

Commitment of chastity - mental and physical purity. It is very important for human to save chastity. The psychology teachers think that feeling of shame, which is given from birth, has an aim - do not follow feelings and passions, physical desires without thinking over about them. They destroy body and mentality. By destroying mentality, a person destroys the work of its display memory, imagination, emotions and feelings, ideation, mind. A human loses an ability to define something that is really good and perfect. By destroying body, a person makes a harm to nervous system - the most important part. It is very harmful for young age, when a body grows and makes stronger. "Melancholy and even insane can be a consequence of this poisonous drawback" [3, p. 46].

A commitment of justice concerning highest human spiritual nature is respect for it, realizing its high honour. And from this point, turns out other important commitment: to respect its main source - the truth, and to avoid any lie.

A commitment of self-love. In scientific ideas of representatives of university psychology under the commitment of self-love is meant the commitment to selfimprovement. This commitment doesn't have nothing in common with self-esteem, with converting all means only for self aims of a person. "Moral love to oneself is love to improvement, that is intrinsic to human's nature; love that is used only legal means" [3, p. 49-50]. It is said, that aim of self-love is improvement as physical nature, and with prevailing moral improvement.

When a person works with his/her physical form, he/she needs refrain from two extremes: excessive care about own body, that influences on psychology of human, making him/her too much tender and sensitive, on the other hand excessive strictness, that burdens and exhausts a body by work and not necessary limits. That's why a task of care about own body for a human has to become its reinforcement. Thus, a person should follow the hygiene rules, do physical exercises.

Care about mentality, according to ethical principle has to be in center of attention of human. To reinforce memory, to develop thinking processes and highest feelings, to reveal and train other displays of mentality, means achieve human's honour. Do not develop positive features of character, do not enrich by knowledge that is unworthy of human, whose destiny is always strives for improvement. When a person works for improvement of psychological processes, he/she needs stick to certain rules and order. The biggest attention a human should pay to development of thinking operations, mind, because it is the main in managing of psychological displays.

The commitment of human concerning moral improvement means: the higher moral is, the more valuable the life is. Taking care about own education and striving for acquisition and display the highest degrees of morality, is the most important commitment of human, which is in center of ethical principle. This is the professor's point of view. For achieving this, a person should work with oneself, work with own will, its strength and firmness, to develop thinking abilities and work with self-analyze, listen to internal voice - conscience. 
Psychological recommendations concerning what a person should do in order to achieve improvement, we find in scientific ideas of representatives of university psychology of 19-th - and the beginning of 20-th century:

1. A person should seek for real and precise realizing about own relationships with other people and moral responsibilities. The means of this is self-knowledge. The more a person knows oneself from psychological side, own nature, honour of own moral nature, has specified with the main goal of own life, the more precisely he/she can realize how to achieve moral order, using own psychological abilities.

2. A person should correspond own actions with ethical rules; by training in this, person forms habits, that will help him/her in overcoming immoral susceptibilities. Acting according to moral laws, a person can attain real wisdom.

3. A person should always listen to own conscience. It shows in what state is the morality of a person, how much it is moral, and from this point depends creating own fortune.

4. Self-improvement should never end. A commitment of a person is to enlarge new knowledge, always work on selfimprovement from physical and psychological point of view, keeping certain criticism concerning own drawbacks and weaknesses and accept different difficulties [1, 2, 3, 4].

A commitment to people. Important role in human's improvement has a society, where a human lives. In this point the teachers of psychology in Ukrainian universities were sure, considering a human as a social creature, and carrying out own activity in it, he/she could achieve moral perfection, doing own deeds with love, or showing immoral susceptibilities, such as egoism.

A commitment of respect to others shows its display firstly in words - honour, truth, and secondly in deeds, mostly corresponding to life and possession of other person. Always tell the truth is a commitment of virtue, because the truth and virtue are indissolubly bound with each other, and where there is no truth, there cannot be virtue. And lie always means disrespect to the person, to whom it is said, and corresponding to this, is not acceptable for commitment of justice.
Protecting life and possession of others is a rule of social justice: exactly for this aim people unite in society, in order to reveal danger, to use protection from others. By following this commitment ensures general order in society.

A commitment of love to humanity means to love others as oneself; to make people happy as much as a person wishes happiness to oneself. Love is displayed in charity, gratitude and participation.

A commitment of gratitude. The gratitude means in particular respect for person, who has done high moral action towards other person. The commitment of gratitude is combined with the commitment of love. The benefit from gratitude requires that a person be grateful for shown respect towards him/her, in order that benefactor will not regret about done actions. The real gratitude shown by human is fair. It doesn't change anytime and doesn't die, even after death of benefactor remains respect for him/her, loves his/her family, and everything that resembles about benefactor.

A commitment of participation. An ability of showing participation - the ability to sympathize with a person who suffers, share happiness with a person who is happy due to sympathy for these people but not due to moral commitment. The participation is considered moral when its source is conscious and well-considered motives. In scientific ideas of representatives of Ukrainian university psychology, we find the following list of motives: esthetical and practical. Esthetical sympathizes reveal in ability to understand emotions of other person, empathy. In case of practical participation, a person understands other person not only by emotions, therefore he/she acts.

Acting according to ethical principles, be moral person, means for a person continuous development, work on own drawbacks and enriching own advantages. Being moral person means be brave and determined, have strong will, control temporary pleasures - "be owner of oneself, refrain from anger, annoyance, despite of own temperament, patiently bear illnesses, sufferings, persecutions, mockeries" [3, p. 71]. Thus, being moral person means to be brave and responsible.

\section{LITERATURE}

1. Авсенев Феофан. Изъ записокъ по психологіи / Феофан Авсенев . К. : Въ Типографіи Кіевскаго Губернскаго Управленія, 1869.-246 с.

2. Новицкий О. М. Руководство къ опытной психологіи / О. М. Новицкий. - К. : Въ Университетской Типографіи, 1840. -488 c.

3. Скворцев И. М. Записки по нравственной философіи / И. М. Скворцев. - К., 1869. - 83 с.

4. Челпанов Г. Учебникъ психологіи (для гимназій и самообразованія) 12-ое изданіе / Г. Челпанов. - М. : Изданіе Т-ва “В. В. Думновъ”, 1915. - 224 с.

\section{REFERENCES}

1. Feofan Afsenev. Iz zapisok po psihologii [Notes of psychology]. 3. Ivan Skvorcev. Zapisky po nravstvennoy filisofii [Notes of Kiev, Tipografiya kievskaho hubernskaho upravleniya Publ., 1869. $246 \mathrm{p}$.

2. Orest Novitckiy. Rukovodstvo $k$ opytnoy psihologii [A handbook of experimental psychology]. Kiev, Universitetskaya typogrfiya Publ., 1840. 488 p.

moral philosophy]. Kiev, 1869.83 p.

4. Georhiy Chelpanov. Uchebnik psykhlogii (dlya himnaziy $i$ samoobrazovaniya) [A textbook of psychology (for gymnasiums and self-education] 12-th edition. Moscow. Izdanie t-va Dumnov Publ., 1915. 224 p.

\section{Психология морального совершенствования человека}

\section{О. А. Мельник}

Аннотация. В статье представлены результаты историко-психологической реконструкции научных идей представителей украинской университетской психологии XIX - начала XX века. Впервые представлен принцип этизма как методологическая основа познания человека в университетской психологии указанного периода. Впервые представлены научные идеи преподавателей курса психологии в университетах Украины в которых высветлена роль нравственного совершенствования в становлении личности, пути его достижения.

Ключевые слова: человек, принцип этизма, совершенствование, воля. 